\title{
FOOD HABITS AND ONTOGENETIC CHANGES IN THE DIET OF WHITEFISH LARVAE IN LAKE ANNECY
}

\author{
O. ANNEVILLE (1)*, L. LAINÉ (1), S. BENKER (1, 2), A. PONTICELLI (1) \\ AND D. GERDEAUX (1)*
}

(1) INRA - Station d'Hydrobiologie Lacustre, BP 511, 75 Avenue de Corzent, 74203 Thonon les Bains Cédex, France.

(2) Limnological Institute, University of Konstanz, 78464 Konstanz, Germany.

* Corresponding authors: Phone: 33 (0)4 50267800 - Fax: 33 (0)4 50260760 - Email: gerdeaux@thonon.inra.fr, orlane.anneville@thonon.inra.fr

Reçu le 14 septembre 2007

Received September 14, 2007

Accepté le 3 Décembre 2007

Accepted December 3, 2007

\begin{abstract}
The ontogenetic changes in the diet of whitefish (Coregonus lavaretus) larvae were investigated during three consecutive years in a deep peri-alpine lake. Identification of the feeding habits of larvae in relation to their larval stage was performed using a PCA\% in order to take into account the individual variability in larval diet. Although whitefish larvae are planktivorous, the present study points out ontogenetic changes in diet. While young larval stages are opportunistic feeders on small copepods, older stages feed preferentially on Daphnia sp.. Strong inter-annual variability has been observed in the dietary overlap between the successive larval stages. We show that the density and availability of the potential prey will affect the dynamics of the ontogenetic changes in the diet. Furthermore, it could probably alter the intra-specific competition between larval stages.
\end{abstract}

Keywords: diet-overlap, dietary, ontogeny, plasticity, whitefish larvae.

\section{HABITUDES ALIMENTAIRES ET CHANGEMENTS ONTOGÉNIQUES DANS L'ALIMENTATION DES LARVES DE CORÉGONES DANS LE LAC D'ANNECY}

\section{RÉSUMÉ}

Les changements ontogéniques du régime alimentaire du corégone (Coregonus lavaretus) ont été étudiés dans un lac profond péri-alpin durant 3 années consécutives. Afin de prendre en compte la variabilité inter-individuelle, les habitudes alimentaires des différents stades de développement larvaire ont été analysées par une ACP\%. Bien que planctivores, la présente étude met en évidence des changements ontogéniques du régime alimentaire chez Coregonus lavaretus. Les jeunes stades sont opportunistes sur les petits copépodes et les stades avancés présentent une préférence pour Daphnia sp. De fortes variabilités inter-annuelles ont pu être observées dans le recouvrement des régimes alimentaires de stades de développement successifs. La densité et la disponibilité des proies potentielles influencent la dynamique des changements ontogéniques et par conséquent pourraient affecter la compétition intra-spécifique entre stades larvaires.

Mots-clés: recouvrement du régime alimentaire, régime alimentaire, ontogénie, plasticité, larve de corégone. 


\section{INTRODUCTION}

Identification of factors impacting survival and future recruitment are of main importance for commercial fishes. While growth and mortality of early hatched larvae can be governed by water temperatures (ECKMANN and PUSCH, 1989) or available zooplankton abundance (MAY, 1974; BRAUM, 1978; HUUSKO, 1998; RELLSTAB et al., 2004), intraspecific competition may occur later in the season of hatching, creating a bottleneck which may influence future recruitment (AUVINEN, 1988). Many fish species are planktivorous during early ontogeny, but distinct shifts in their feeding habits may occur during their development (NUNN et al., 2007). Ontogenetic diet patterns have already been studied for a variety of marine and freshwater fishes (LINDSAY et al., 1998; MITTELBACH and PERSSON, 1998, MCELROY et al., 2006, REZSU and SPECZIAR, 2006; NUNN et al., 2007). Ontogenetic shifts have been shown to render the intra and inter-specific relationships complex. They can affect not only individuals but also populations and communities (KAHILAINEN et al., 2005, TAKIMOTO, 2003). Diet variation within population may alter the dynamics of interaction and relax intra-specific competition. Changes in intra-specific competition by resource partitioning have been observed in many species (POLIS, 1984, CHOUINARD and BERNATCHEZ, 1998; BOLNICK et al., 2003). As resource limitation can be an important cause of mortality at the larval stage (CUSHING, 1990; HUUSKO, 1998; RELLSTAB et al., 2004), relaxing competition for resources by the way of ontogenetic shifts can be an ecological process maximizing survival at the larval stage.

Whitefishes (Coregonidae) often support major commercial fisheries. Their biology and ecology have been extensively studied for several decades. The studies have mainly examined habitat uses, diet, growth, reproductive characteristics and their sensitivity to environmental fluctuations induced by climate variability and eutrophication (ECKMANN, 1991, KAHILAINEN et al., 2005, STRAILE et al., 2007, THOMAS and ECKMANN, 2007). During larval growth, whitefish diet evolves (LINDSTRÖM, 1988, PONTON and MÜLLER, 1989, CRETENOY and GERDEAUX, 1997), being strongly related to the available prey organisms (PONTON and MÜLLER, 1989). However, there is only little information about diet partitioning patterns among larval stages and how it can be impacted by inter-annual fluctuations in zooplankton composition. Furthermore, investigations on diets in fish ecology are mostly based upon the analysis of stomach contents and the use of indices designed to study at the population level. Most of the studies do not consider variation in the use of resources by each individual, whereby differences among the feeding habits of individual fish were neglected. Although this simplification can be justified if inter-individual niche variations are rare or have no real ecological implications, individual specialization is however widespread and might have some implication at the population level (BOLNICK et al. 2003).

The present study was designed to examine the ontogenetic changes in individual diet and feeding habits of the whitefish $C$. lavaretus L., the main commercial fish in French peri-alpine lakes. The aims of the study were to identify year-to-year variations in larval diets and individual specialization of whitefish larvae during their growth in relation with the available zooplankton. Through this field study we hope to improve the understanding of the impact of food competition in the dynamics of the recruitment of whitefish larvae.

\section{METHODS}

Field samples: The study took place in Lake Annecy, a deep warm monomictic peri-alpine lake (surface: $27 \mathrm{~km}^{2}$, mean depth: $41 \mathrm{~m}$, max depth: $65 \mathrm{~m}$ ) located in France at $446.97 \mathrm{~m}$ of altitude.

Larvae were sampled weekly during three successive years 2004, 2005 and 2006. Sampling took place in the littoral zone from the beginning of larvae hatching (end of 
February) until the larvae could not be caught any more with our method (beginning of May). The larvae were collected in the early morning. They were sampled within the first meter of the water column using two rectangular $1 \mathrm{~mm}$-mesh nets (width $=1.5 \mathrm{~m}$, height= $1 \mathrm{~m}$, length $=5 \mathrm{~m}$ ) towed on both sides of a motorboat at a speed of $1.9 \mathrm{~km} \cdot \mathrm{h}^{-1}$, along transects parallel to the coast in 2004 and 2005. During the first year, whitefish larvae were sampled using a circular $1 \mathrm{~mm}$-mesh net (diameter $=1.5 \mathrm{~m}$, length $=4 \mathrm{~m}$ ) towed between 30-50 $\mathrm{m}$ behind the motorboat.

Zooplankton was collected at a sampling station located in the area of larvae sampling, using a $200 \mu \mathrm{m}$ mesh size zooplankton net during one vertical haul from $20 \mathrm{~m}$ to the surface. The sample was preserved immediately in $5 \%$ formalin solution.

Samples preparation: Total length of larvae was measured to $0.5 \mathrm{~mm}$ and the larval developmental stage (LDS) was identified according to LUCZYNSKI et al. (1988). Larval diet was evaluated by dissecting the entire gut contents. Ingested prey were identified and counted at the genus and developmental stage level under a microscope (magnification: 40x).

Statistical analysis: The diet of larvae was investigated using a multivariate method specifically designed for diet composition data. The method has been described by DE CRESPIN DE BILLY et al. (2000). It is based on a principal component analysis (PCA) performed on a proportion table. The initial data matrix contains the absolute abundances of prey items found in the gut contents of the 636 larvae. We distinguished 6 categories of prey: calanoids (Cal), nauplii of calanoids and cyclopoids (Nau), copepodite stages $\mathrm{C}_{1}$ to $\mathrm{C}_{3}$ of cyclopoids $\left(\mathrm{Cy}_{1-3}\right)$, copepodite stages $\mathrm{C}_{4}$ and $\mathrm{C}_{5}$ of cyclopoids $\left(\mathrm{Cy}_{4-5}\right)$, adults of cyclopoids $\left(\mathrm{Cy}_{\mathrm{Ad}}\right)$ and herbivorous cladocerans (Clad). The herbivorous cladocerans found in the gut contents were mainly Daphnia hyalina-galeata and few Eubosmina longispina. The matrix is thus made of 6 variables (the categories of prey) and 636 objects (the larvae). The transformation of the matrix consisted in a percentage per row in order to have each row total equal to 1 and then a centring per column. The PCA\% was run using ADE4 software (THIOULOUSE et al., 1997).

Strategy was represented by two indices. The first one is a frequency of occurrence. It quantifies the fidelity of a prey to a larval stage: Fidelity index $\left(F_{k j}\right)$. This index is at maximum when the prey $\mathrm{j}$ is present in all the guts of stage $\mathrm{k}$ larvae

$\mathrm{F}_{\mathrm{kj}}=$ Nlarvae $_{\mathrm{kj}}{ }^{*}\left(\text { Nlarvae }_{\mathrm{k}+}\right)^{-1}$

Nlarvae $_{k j}$ : number of larvae of stage $k$ where prey $j$ is present

Nlarvae $_{\mathrm{k+}}$ : total number of larvae of stage $k$ with no empty gut

The second index indicates the contribution of a prey to the diet of a larval stage: Prey-specific abundance index $\left(P_{i}\right)$. This index is at maximum when the prey $j$ is the only prey found in the gut of stage $\mathrm{k}$ larvae that have eaten this prey.

$\mathrm{P}_{\mathrm{kj}}=\left(\Sigma \mathrm{S}_{\mathrm{kj}}^{*}\left(\Sigma \mathrm{S}_{\mathrm{kt}}\right)^{-1}\right)^{*} 100$

$S_{k j}$ : gut content (number) comprised of prey j for stage $k$ larvae

$\mathrm{S}_{\mathrm{kt}}$ : total gut content in only those stage $\mathrm{k}$ larvae with prey $\mathrm{j}$ in their gut

In order to interpret the feeding strategy of each larval stage, the prey-specific abundance was plotted against the fidelity on a two-dimensional graph (feeding strategy diagram), as suggested by AMUNDSEN et al., 1996. Moving along the vertical axis gives an indication on the feeding strategy in terms of specialization or generalization. The horizontal axis illustrates the homogeneity of the individual in the sample. Prey points positioned in the upper left (high specific abundance and low fidelity) will have been consumed by a few individuals but make up the main item of the diet. Prey points positioned in the lower right will have been eaten occasionally by most individuals. Prey points positioned in the upper right will have been consumed by most individuals displaying a predilection for that prey. In that case it indicates that the population is specialized. 
Diet overlap between LDS was examined using the Schoener index (SCHOENER, 1970):

$$
\alpha=1-0.5\left(\sum_{i=1}^{n}\left|P_{x i}-P_{y i}\right|\right)
$$

where $n$ is the number of prey categories, $P_{x i}$ is the proportion of food item $i$ used by LDS $x$ and $\mathrm{P}_{y i}$ is the proportion of food item $i$ used by LDS $y$. For the following analysis we considered $y$ as: $y=x+r$, where $r$ was the lag for between LDS comparisons. An overlap value of 1 suggests complete overlap and a value of 0 indicates no overlap.

Prey selection was investigated for the 9 larval stages. Electivity index indicates the prey preference taking into account the in-situ zooplankton composition (IVLEV, 1961).

$$
\mathrm{E}=\left(\mathrm{r}_{i}-\mathrm{p}_{i}\right)^{*}\left(\mathrm{r}_{i}+\mathrm{p}_{i}\right)^{-1}
$$

Where $r_{i}$ is the relative abundance (\%) of a specific food item in the gut, $p_{i}$ is the relative abundance of the same food item in the environment. The index can show values between -1 and 1 . A positive value close to +1 indicates strong positive selection (or preference), 0 indicates no selection and -1 indicate strong negative selection (or total avoidance).

\section{RESULTS}

Whitefish larvae were captured from February to May, a time-period that covers the C. lavaretus hatching season in Lake Annecy. In total, 636 larvae ranging between $11 \mathrm{~mm}$ and $30 \mathrm{~mm}$ were collected and used for gut contents analysis. The samples used in this study consisted in larval development stages ranging between 1 and 9 (Table I).

Whitefish larvae started to feed before the complete resorption of the yolk sac. In Lake Annecy, C. lavaretus diet consisted entirely of copepods and cladocerans. The relative proportion of the different prey items varied with the ontogenetic stages and presented strong inter-annual fluctuations, as did the composition of the crustacean community in the lake (Fig. 1).

With development from LDS1-3 to LDS4, the importance of cyclopoids was declining while that of Daphnia sp. was increasing. The feeding strategy plots, computed for 2004 (Fig. 2), indicated that the populations of young stages from LDS-1 to LDS3 were specialized on small cyclopoids and most individuals consumed $\mathrm{Cy}_{4-5}$ whose specific abundance was less than 0.5. No clear strategy appeared for LDS-4. LDS-7 and LDS-8 appeared to be quite specialized on Daphnia sp.. Change in prey selection during ontogeny was confirmed by the electivity index that took into account the composition of the zooplankton community in the lake (Fig. 3). Calanoids and nauplii were not eaten by the larvae. Electivity index computed for $\mathrm{Cy}_{1-3}$ was positive for young larvae and became negative for older ones. No selection appeared on $\mathrm{Cy}_{4-5}$ as well as for $\mathrm{Cy}_{\mathrm{Ad}}$ that were avoided by young larval. As the larvae developed, they preferentially fed on Daphnia sp. that supported a strong positive selection by old larval stages.

Analysis of diet overlap revealed strong inter-annual fluctuations. There was a high degree of overlap in the diets of contiguous LDS, with the exception of LDS 6 and 7 in 2004, and LDS-5 and 6, LDS-7 and 8, and LDS-8 and 9 in 2006 (Table II). Diet overlap decreased with increasing the lag of comparison. Generally, comparing young and old stages (from lag $>3$ ) showed very low diet overlap values, suggesting quite different diets. However, in 2005 diet overlap between young and old larvae remained high compared to the other years. During this year Daphnia sp. had a low contribution to the in-situ zooplankton composition and LDS-1 to LDS-6 presented quite similar diets with old larvae still having a diet dominated by $\mathrm{Cy}_{4-5}$ (Fig. 1). 


\section{Table I}

Larval developmental stages (LDS), total number of guts analysed (N) of $C$. lavaretus larvae captured in Lake Annecy in 2004, 2005 and 2006, mean total length $\left(\mathrm{L}_{\mathrm{T}}\right)$, standard deviations (st. dev.) and description of stages according to LUCZYNSKI et al., 1988.

Tableau I

Stades de développement larvaire (LDS), nombre d'intestins analysés (N) provenant des captures effectuées au Lac d'Annecy en 2004, 2005 et 2006, longueur totale moyenne ( $\left.L_{T}\right)$, écart-type (st. dev) et description d'après LUCZYNSKI et al. (1988) des stades observés.

\begin{tabular}{|c|c|c|c|l|}
\hline LDS & $\mathrm{N}$ & $\mathrm{L}_{\mathrm{T}}(\mathrm{mm})$ & st. dev. & \multicolumn{1}{|c|}{ Description of stages } \\
\hline 1 & 207 & 13 & \pm 1 & Yolk sac protrudes from the body surface \\
\hline 2 & 186 & 14 & \pm 1 & Pelvic fin buds present \\
\hline 3 & 110 & 17 & \pm 2 & Fin rays at the bases of dorsal and anal fin \\
\hline 4 & 57 & 19 & \pm 2 & Fin rays in the whole length of caudal fin \\
\hline 5 & 39 & 21 & \pm 2 & $\begin{array}{l}\text { Dorsal fin fold divided into dorsal and adipose } \\
\text { fins, swim bladder filled with air }\end{array}$ \\
\hline 6 & 11 & 23 & \pm 1 & $\begin{array}{l}\text { Fin rays in the whole length of pelvic fins, } \\
\text { pneumatic duct forms characteristic loop }\end{array}$ \\
\hline 7 & 17 & 25 & \pm 1 & $\begin{array}{l}\text { Fin rays along the whole length of dorsal and } \\
\text { anal fins, stomach fully curved, pyloric caeca } \\
\text { recognizable }\end{array}$ \\
\hline 8 & 6 & 27 & \pm 2 & $\begin{array}{l}\text { Disappearance of the part of fin fold anterior to } \\
\text { pelvic fins }\end{array}$ \\
\hline 9 & 3 & 29 & \pm 1 & Bases of adipose and anal fins equal in length \\
\hline
\end{tabular}

Patterns in individual diet were investigated using the PCA\% (Fig. 4). According to the eigenvalues, the first two axes of the PCA\% were sufficient to illustrate the main structure of the diet composition (Fig. 4a). They explained respectively $49 \%$ and $29 \%$ of the total variability. The first axis was mainly explained by the linear combination of $\mathrm{Cy}_{4-5}$ and $\mathrm{Cy}_{1-3}$. The second axis was explained by copepodites of cyclopoids, adults of cyclopoids and herbivorous cladocerans. The distribution of the individual larvae in the first plane made of axis I and II revealed patterns associated to the developmental stage level (Fig. 4b). There was strong inter-individual variability for the young developmental stages. LDS-1 to LDS-3 were distributed all over the plane but concentrated mainly between $\mathrm{Cy}_{4-5}$ and $\mathrm{Cy}_{1-3}$. LDS-4 to LDS-6 concentrated between $\mathrm{Cy}_{\mathrm{Ad}}$, cladocerans and Cy $\mathrm{y}_{4-5}$. LDS-7 to LDS-9 were grouped together around cladocerans and $\mathrm{Cy}_{\mathrm{Ad}}$, indicating that they feed preferentially on these two categories of zooplankton. A grouping of individuals by LDS, indicated ontogenetic changes along axis 2 (Fig. 4c) with scores being significantly different for the successive LDS (Kruskal-Wallis, $P<0.001$ ). The main variance expressed by axis I indicated strong inter-individual variability associated with the year of catch (Fig. 4c), the inter-annual differences of the scores of the larvae being significantly different (KruskalWallis, $P<0.001$ ). Furthermore, the distribution of the diet on axis I was significantly correlated with the contribution of $\mathrm{Cy}_{4-5}$ and $\mathrm{Cy}_{1-3}$ to the available prey in the lake (Table III). While the young LDS were both influenced by the in-situ relative abundance of $\mathrm{Cy}_{1-3}$ and $\mathrm{Cy}_{4-5}$, older larvae were only influenced by the in-situ abundance of the larger copepodite stages. The inter-individual variability in the diet of the young larval developmental stages expressed by axis I, appeared thus strongly influenced by the temporal fluctuation in the in-situ zooplankton composition. 

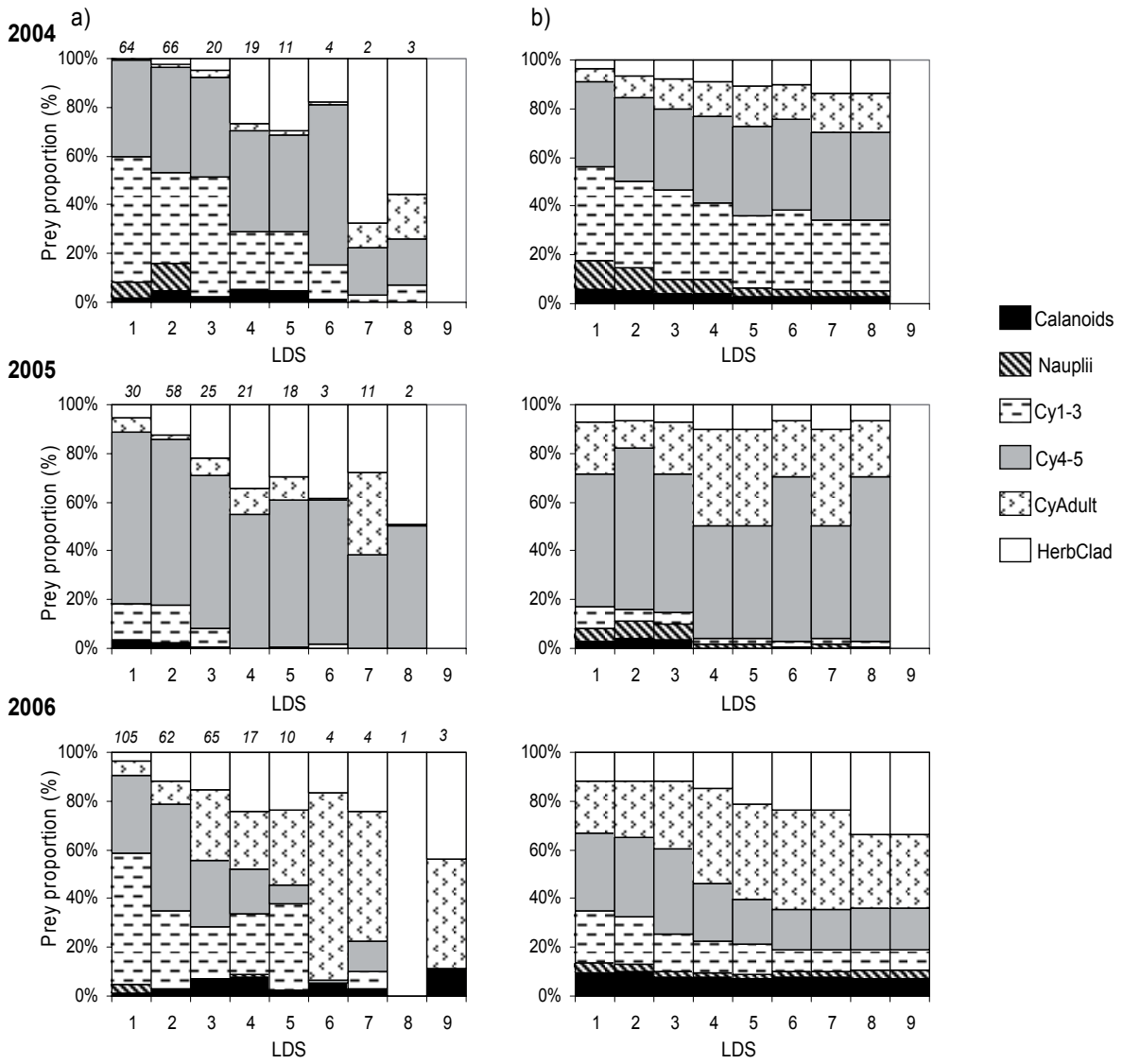

Figure 1

A) Proportion of food items in whitefish larvae of successive developmental stages for the years 2004, 2005 and 2006. Number of whitefish guts studied is indicated above bars.

B) Proportion of zooplankton taxa in Lake Annecy when the corresponding larval stages were sampled.

\section{Figure 1}

A) Proportion des taxons ingérés par chaque stade de développement larvaire en 2004, 2005 et 2006. Le nombre d'intestins analysés est précisé en haut de la figure.

B) Proportion des taxons présents dans le lac au moment où les différents stades de développement larvaires ont été capturés.

\section{DISCUSSION}

In Lake Annecy, hatching occurs continually during three months from the end of February until the end of April. Whitefish larvae gather in the littoral zone during their larval stages.

Although whitefish larvae are planktivorous during the early ontogeny, they fed on different crustacean groups. The PCA\% used in this analysis detects the patterns in individual diet and foraging behaviour. It allows to detect an overall feeding plasticity (opportunism) on copepodite stages and diet specialization of old larvae toward Daphnia $s p$.. These ontogenetic changes are consistent with previous studies that demonstrated a switch from a small copepod to a Daphnia sp. dominated diet (LINDSTRÖM, 1988, 

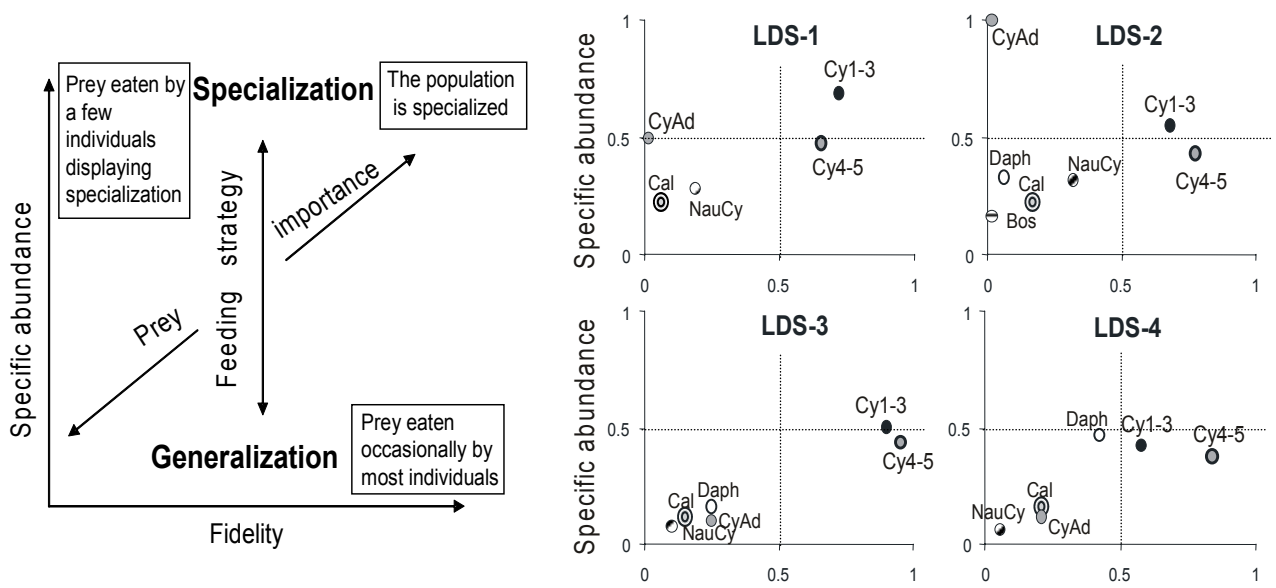

$\begin{array}{ll}\text { O NauCy } & \text { ○ Cal } \\ \text { - Cy1-3 } & \text { O Daph } \\ \text { OCy4-5 } & \ominus \text { Bos } \\ \text { CyAd } & \end{array}$
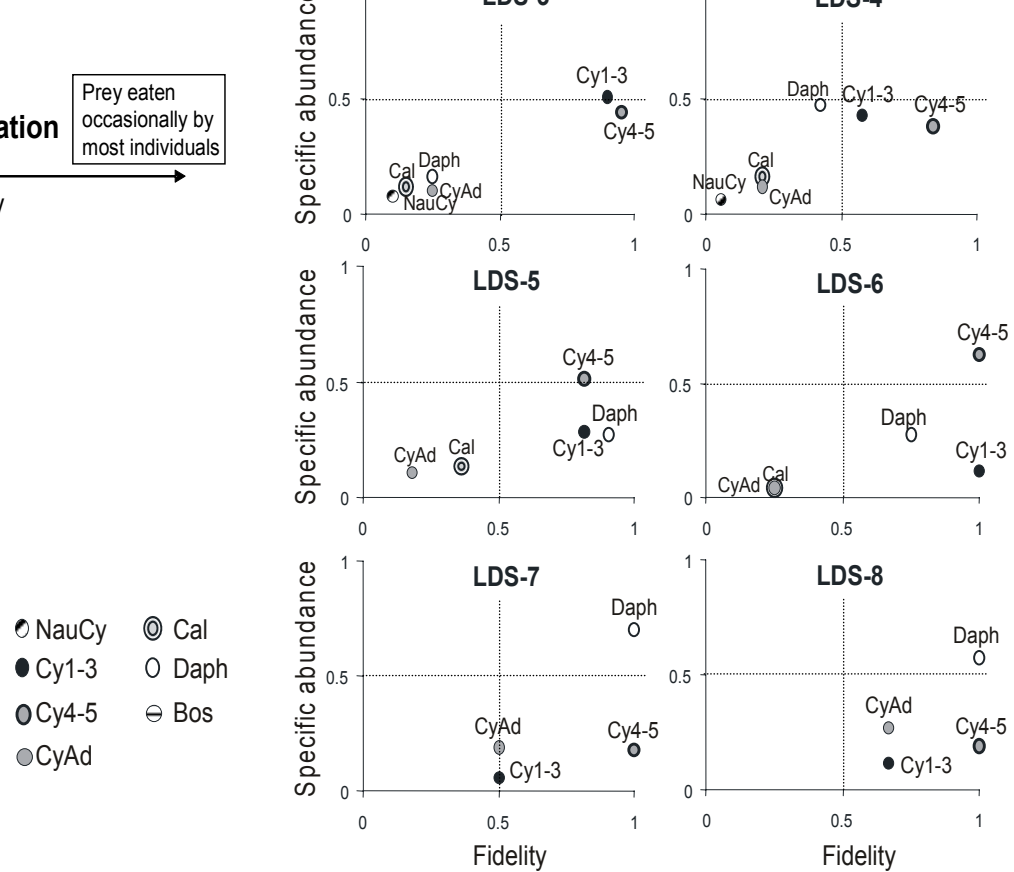

Figure 2

Feeding strategy diagram as suggested by AMUNDSEN et al. (1996): preyspecific abundance plotted against frequency of occurrence of a prey in the diet of the predator in 2004.

Figure 2

Diagramme de stratégie alimentaire selon le modèle de AMUNDSEN et al. (1996): l'abondance spécifique des proies est représentée en fonction de leur fréquence d'occurrence dans le bol alimentaire du prédateur en 2004.

PONTON and MÜLLER, 1989). Daphnia appears therefore as indicator prey for LDS-7 and 8 larvae that exert a specific predatory strategy on this taxon even if it does not yet represent the dominant component of the zooplankton community. The dominant preys are cyclopoid copepodites for LDS ranging between 1 and 3. In Lake Annecy, young larvae scarcely feed on nauplii or calanoids while these taxa have been recorded as potential prey for C. lavaretus in other lakes (PONTON and MÜLLER, 1989). These differences between the results can be explained by the low abundance of nauplii and calanoids compared to other copepods in Lake Annecy. Furthermore, in contrast to planktivores which can normally ingest the full range of zooplankton sizes present in lakes, fish larvae are initially gape limited (ZARET, 1980). In Lake Annecy, Mixodiaptomus laciniatus is the unique calanoid species, it is quite large compared to the other copepods taxa and probably does not suit larvae gape. 

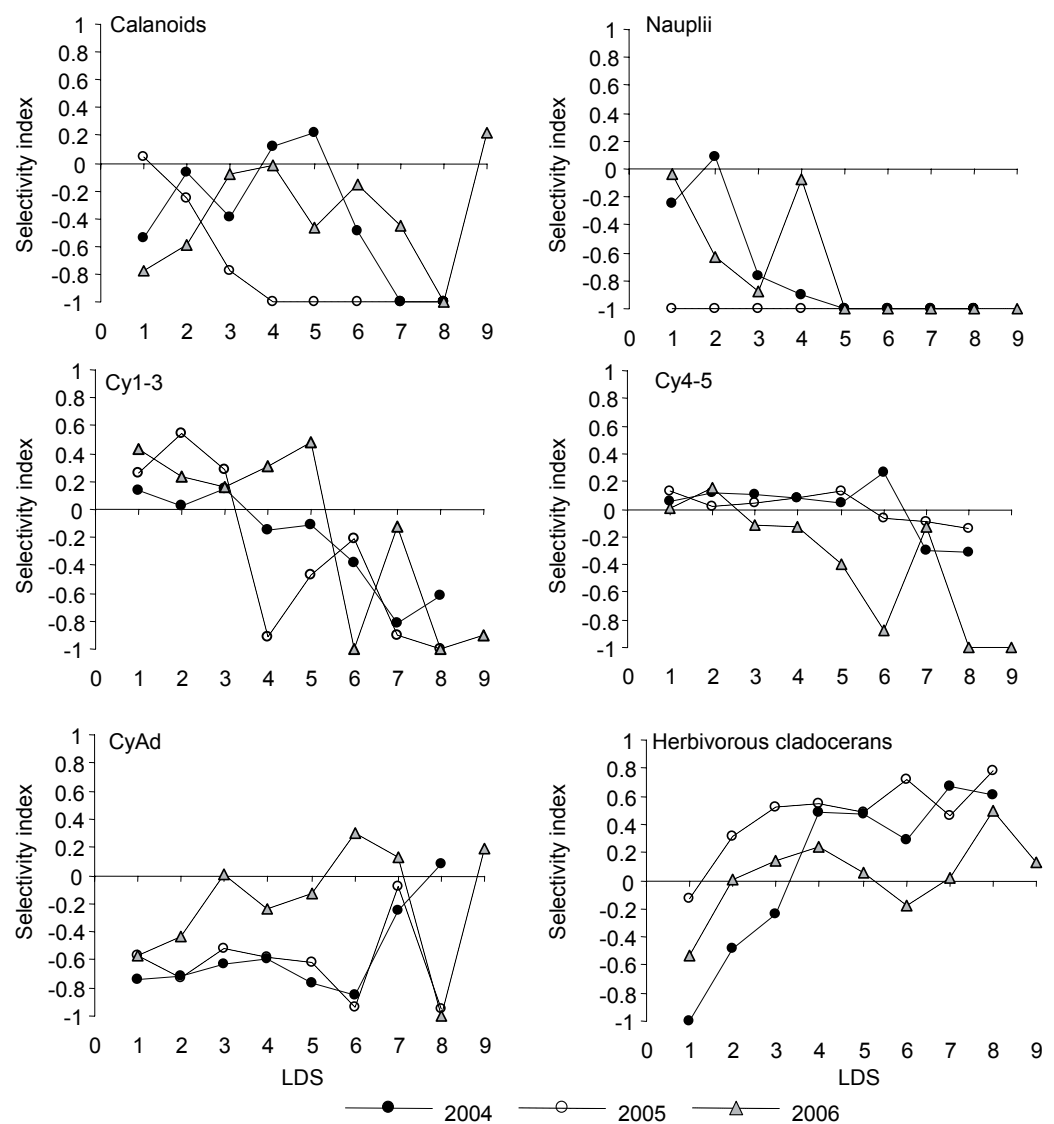

\section{Figure 3}

Ontogenetic changes in the selectivity index (IVLEV, 1961) for the different food Figure 3 items found in the larvae guts during the three years of the study.

Changements ontogénétiques de l'indice de sélectivité (IVLEV, 1961) pour les différents taxons identifiés dans les intestins des larves au cours des trois années d'étude.

The present results support the ontogenetic diet shift described in other studies for other coregonid species (CHOUINARD and BERNATCHEZ, 1998; HUUSKO, 1998; ENZ, 2000). They demonstrate that changes in the diet correlate with the transition from young larvae without complete fin rays to old larvae with formation of the fin completed and swim bladder filled with air. Medium larvae (LDS-4 to LDS-6) have intermediate diet whose composition is strongly influenced by the composition of the zooplankton community. Depending on the year, high overlaps commonly occur between successive stages while few minor overlaps in diet were found between young (LDS-1 to LDS-3) and old larvae (LDS-7 till LDS-9). Such ontogenetic changes lead to resource partitioning during the developmental stages. 
Table II

Diet overlap patterns of $C$. lavaretus larvae for three successive years. The colors indicate the strength of the overlap: no overlap in black, medium and pronounced overlaps in grey and white respectively.

Tableau II

Recouvrement des régimes alimentaires des larves de C. lavaretus pour les trois années successives. La couleur indique le degrés de recouvrement: pas de recouvrement en noir, recouvrement moyen et fort en gris et blanc respectivement.

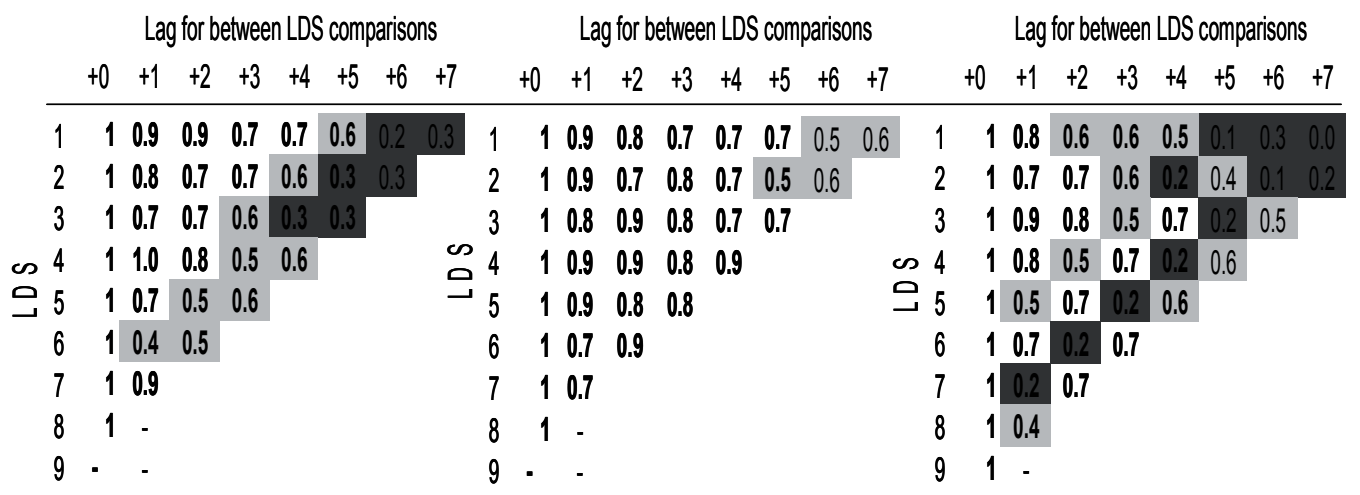

Table III

Pearson correlations coefficients between individual scores on axis I (see Fig. 4b) and in-situ relative abundances of $\mathrm{Cy}_{4-5}$ and $\mathrm{Cy}_{1-3}$. Relative abundances are expressed as the contribution of $\mathrm{Cy}_{4-5}$ or $\mathrm{Cy}_{1-3}$ to the total abundance of the prey having a significant contribution to the formation of the axes I and II (Daphnia sp. and cyclopoids). The column " $\mathrm{Nb}$ " indicates the number of larvae scores used for the correlations. Bold values are significant (P-value<0.05).

Tableau III

Coefficients de corrélations de Pearson calculés entre les scores des individus sur l'axe I (voir Fig. 4b) et l'abondance relative de $\mathrm{Cy}_{4-5}$ et $\mathrm{Cy}_{1-3}$ dans le milieu. Les abondances relatives sont exprimées en tant que contributions de $\mathrm{Cy}_{4-5}$ ou $C y_{1-3}$ à l'abondance totale des proies ayant une contribution significative à la formation des axes I et II (Daphnia sp. et cyclopoïdes). La colonne "Nb" indique le nombre de scores utilisés pour le calcul des corrélations. Les valeurs en gras sont significatives ( $\mathrm{P}$-value<0.05).

\begin{tabular}{|c|c|c|c|}
\hline LDS & \%Cy4-5 & \%Cy1-3 & $\mathrm{Nb}$ \\
\hline 1 & $\mathbf{0 . 5 4}$ & $-\mathbf{0 . 4 9}$ & 207 \\
\hline 2 & $\mathbf{0 . 4 5}$ & $-\mathbf{0 . 3 8}$ & 186 \\
\hline 3 & $\mathbf{0 . 6 9}$ & -0.22 & 110 \\
\hline 4 & $\mathbf{0 . 6 9}$ & -0.09 & 57 \\
\hline 5 & $\mathbf{0 . 7 9}$ & -0.17 & 39 \\
\hline 6 & $\mathbf{0 . 8 3}$ & 0.27 & 11 \\
\hline 7 & $\mathbf{0 . 9 1}$ & -0.25 & 17 \\
\hline 8 & $\mathbf{0 . 8 2}$ & -0.42 & 6 \\
\hline
\end{tabular}




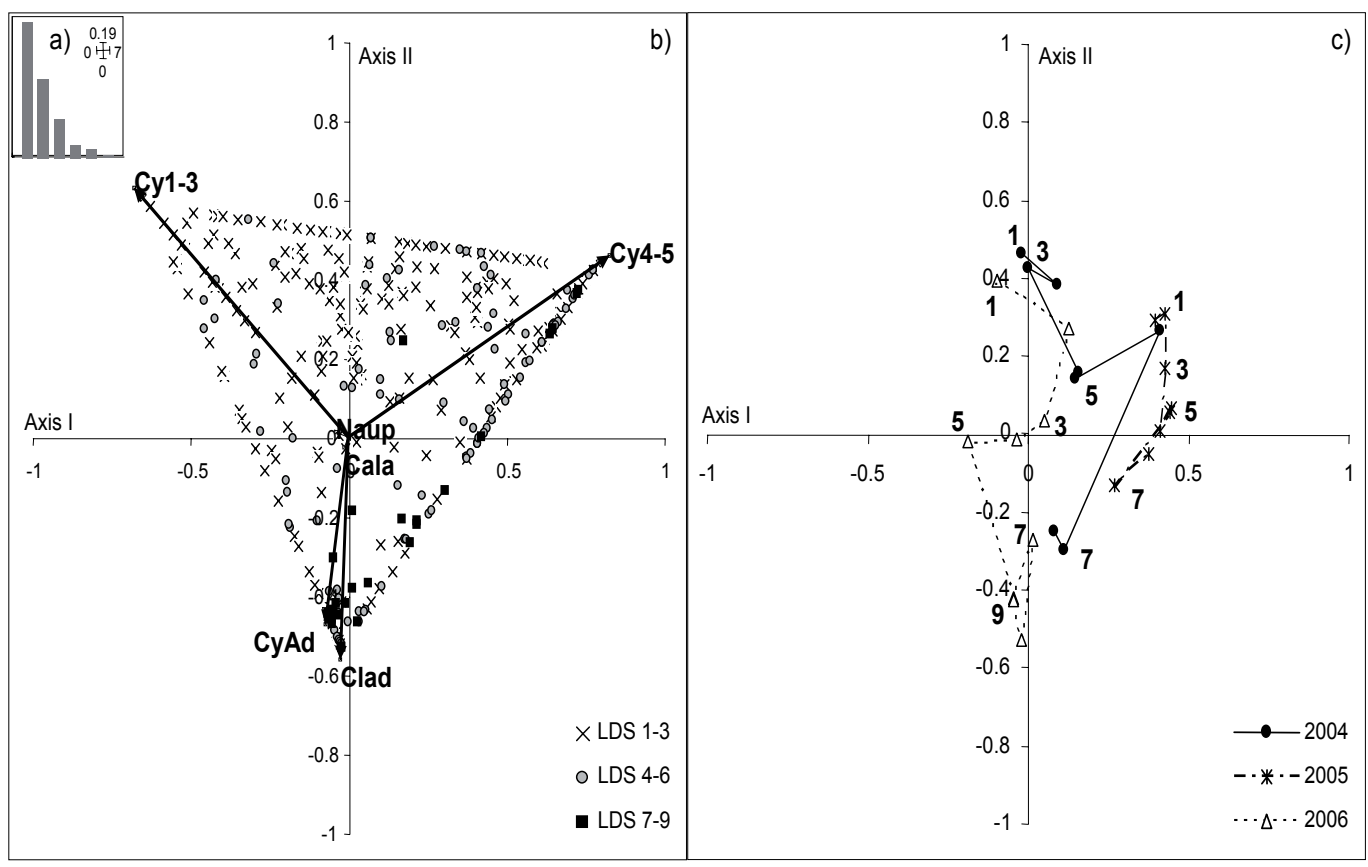

Figure 4

Biplot of prey items and LDS obtained from the\%PCA.

A) Histogram of eigenvalues,

B) Distribution of the individual gut contents for the successive LDS on the first factorial plane according to their prey items (arrows). Young larvae are represented by crosses (LDS-1 to 3), middle larvae are represented by circles (LDS-4 to 6) and old larvae are represented by squares (LDS-7 to 9).

C) Distribution of the centre of gravity of the LDS for each year on the first factorial plane. The labels next to the points indicate the LDS.

\section{Figure 4}

Biplot des taxons et SDL obtenus par l'ACP\%.

A) Histogramme des valeurs propres,

B) répartition des larves dans le premier plan selon la composition de leur contenu stomacal (flèches). Les jeunes larves sont représentées par des croix (SDL-1 à 3), les larves intermédiaires sont représentées par des cercles (SDL4 à 6), les larves plus âgées sont représentées par des carrés (SDL-7 à 9).

C) Répartition dans le premier plan, des centres de gravité de chaque SDL pour chaque année. Le chiffre indique le SDL.

The results of the PCA\% showed that the main variability in the diet is explained by inter-annual fluctuations in the in-situ zooplankton composition. These results are consistent with previous studies showing that the composition of $C$. lavaretus larvae diet depends not only on the ability of the larvae to catch the prey but also on the abundance of the zooplankton taxa present in the distribution area of the larvae (PONTON and MÜLLER, 1989). The strong relationship between larvae diet and the composition of available zooplankton leads to inter-annual fluctuations in diet-overlap between LDS. These observations suggest that the success of ontogenetic shift is mainly influenced by the abundance of usable zooplankton size and species. As shown by the present results, strong diet overlap occurs in years (e.g. 2005) when Daphnia is not abundant compared 
to $\mathrm{Cy}_{4-5}$, a prey that is consumed by all the LDS. In contrast, when the relative abundance of the different preys is similar, the food preference of the successive LDS can express, resulting in low diet overlaps. By choosing the more abundant prey, intermediate LDS decrease the cost of prey capture in term of energy and time (PONTON and MÜLLER, 1990). This opportunistic strategy results in a variable timing of ontogenetic diet shifts. Plasticity in the timing of ontogenetic niche shifts has been reported to have a stabilizing effect on consumer-resource dynamics (TAKIMOTO, 2003). Such plasticity based on the resource availability tends to increase predation on the more abundant resource and thus the scarce resource tends to increase (TAKIMOTO, 2003).

In conclusion, gut content analysis has been a standard technique to investigate the diet of fishes. The statistical methods applied in this study allow characterising the diet of C. lavaretus larvae in Lake Annecy. Unfortunately, only few old larvae were available for this study. Still, the methods used have allowed identifying ontogenetic changes in larval diet. The present study confirms that the dynamics of these ontogenetic changes are affected by the density and availability of the potential prey that could thus alter the intraspecific competition between young larval stages. The ecological implications and the assessment of the impact of such a competition on the recruitment will however require more field studies.

\section{ACKNOWLEDGEMENTS}

The authors thank Jean-Christophe Hustache and Michel Colon for their technical help during sampling. The authors are grateful to Reiner Eckmann for his collaboration in the supervision of SB during her Diplomarbeit from the University of Constance (Germany).

\section{REFERENCES}

AMUNDSEN P.A., GABLER H.M., STALDVIK F.J., 1996. A new approach to graphical analysis of feeding strategy from gut contents data modification of the Costello (1990) method. Journal of Fish Biology, 48, 607-614.

AUVINEN, H., 1988. Factors affecting the year-class strength of vendace (Coregonus albula (L.)) in Lake Pyhäjärvi (Karelia, SE Finland). Finnish Fisheries Research, 9, 235-243.

BOLNICK D.I., SVANBÄCK R., FORDYCE J.A., YANG L.H., DAVIS J.M., HULSEY C.D., FORISTER M.L., 2003. The ecology of individuals: Incidence and implications of individual specialization. The American Naturalist, 161,1-28.

BRAUM E., 1978. Ecological aspect of the survival of fish eggs, embryos and larvae. In: GERKING S.D. (Ed.), Ecology of Freshwater Fish Production, 102-131, Blackwell Scientific Publications, Oxford.

CHOUINARD A., BERNATCHEZ L., 1998. A study of trophic niche partitioning between larval populations of reproductively isolated whitefish (Coregonus $s p$.) ecotypes. Journal of Fish Biology, 53, 1231-1242.

CRETENOY L., GERDEAUX D., 1997. Croissance et alimentation des larves de corégones (Coregonus lavaretus) dans le lac d'Annecy de mars à avril 1996. Bull. Fr. Pêche Piscic., 346, 519-526.

CUSHING D.H., 1990. Plankton production and year-class strength in fish populations: an update of the match/mismatch hypothesis. Advenced in Marine Biology, 26, 249-293. 
DE CRESPIN DE BILLY V., DOLEDEC S., CHESSEL D., 2000. Biplot presentation of diet composition data: an alternative for fish gut contents analysis. Journal of Fish Biology, 56, 961-973.

ECKMANN R., 1991. A hydroacoustic study of pelagic spawning behavior of whitefish (Coregonus lavaretus) in Lake Constance. Canadian Journal of Fisheries and Aquatic Sciences, 48, 995-1002.

ECKMANN R., PUSCH M., 1989. The influence of temperature on growth of young coregonids (Coregonus lavaretus L.) in a large prealpine lake. Rapports et procèsverbaux des réunions - Conseil international pour l'exploitation de la mer, 191, 201-208.

ENZ C.A., 2000. Population dynamics of whitefish (Coregonus suidteri Fatio) in artificially oxygenated Lake Hallwil, with special emphasis on larval mortality and sustainable management. Dissertation, Swiss federal institute of technology, Zurich, 177 p.

HUUSKO A., 1998. Exploration of potential mechanisms regulating survival in the larval stage of vendace. Acta Universitatis Ouluensis, A 309. Oulu University press, Oulu.

IVLEV V.S., 1961. Experimental ecology of the feeding of fishes. Yale University Press, New Haven, Cl.

KAHILAINEN K., ALAJÄRVI E., LEHTONEN H., 2005. Planktivory and diet-overlap of densely rakered whitefish (Coregonus lavaretus (L.)) in a subarctic lake. Ecology of Freshwater Fish, 14, 50-58.

LINDSAY D.J., MINAGAWA M., MITANI I., KAWAGUCHI K., 1998. Trophic shift in the Japanese anchovy Engraulis japonicus in its early life history stages as detected by stable isotope ratios in Sagami Bay, Central Japan. Fisheries science, 64, 403-410.

LINDSTRÖM T., 1988. Diet change during metamorphosis in whitefish. Finnish Fisheries Research, 9, 89-105.

LUCZYNSKI M., FALKOWSKI S., KOPECKI T., 1988. Larval development in four coregonid species (Coregonus albula, C. lavaretus, C. muksun and C. peled). Finnish Fisheries Research, 9, 61-69.

MAY R.C., 1974. Larval mortality in marine fishes and the critical period concept. In: BLAXTER J.H.S. (Ed.), The early life history of fish, 3-19, Springer Verlag, Berlin.

MCELROY W.D., WETHERBEE B.M., MOSTELLO C.S., LOWE C.G., CROW G.L., WASS R.C., 2006. Food habits and ontogenetic changes in the diet of the sandbar shark, Carcharhinus plumbeus, in Hawaii._Environmental Biology of Fishes, 76, 81 - 92.

MITTELBACH G.G., PERSSON L., 1998. The ontogeny of piscivory and its ecological consequences. Canadian Journal of Fisheries and Aquatic Sciences, 55, 14541465.

NUNN A.D., HARVEY J.P., COWX I.G., 2007. The food and feeding relationships of larval and 0+year juvenile fishes in lowland rivers and connected waterbodies. I. Ontogenetic shifts and interspecific diet similarity. Journal of Fish Biology, 70, 726742.

POLIS G.A., 1984. Age structure component of niche width and intraspecific resource partitioning: can age groups function as ecological species? The American Naturalist, 123, 541-564.

PONTON D., MÜLLER R., 1989. Alimentation et facteurs de mortalité des larves de corégones (Coregonus sp.). Exemple de deux lacs de niveaux trophiques différents: les lacs de Saren et de Hallwil (Suisse Centrale). Aquatic Sciences, 51, 67-83. 
PONTON D., MÜLLER R., 1990. Size of prey ingested by whitefish, Coregonus sp. larvae. Are Coregonus larvae gape-limited predators? Journal of Fish Biology, 36, 67-72.

RELLSTAB C., BÜRGI H.R., MÜLLER R., 2004. Population regulation in coregonids: the significance of zooplankton concentration for larval mortality. Annales Zoologici Fennici, 41, 281-290.

REZSU E., SPECZIAR A., 2006. Ontogenetic diet profiles and size-dependent diet partitioning of ruffe Gymnocephalus cernuus, perch Perca fluviatilis and pumpkinseed Lepomis gibbosus in Lake Balaton. Ecology of Freshwater Fish, 15, 339-349.

SCHOENER T.W., 1970. Non-synchronous spatial overlap of lizards in patchy habitats. Ecology, 51, 408-418.

STRAILE D., ECKMANN R., JÜNGLING T., THOMAS G., LÖFFLER H., 2007. Influence of climate variability on whitefish (Coregonus lavaretus) year-class strength in a deep, warm monomictic lake. Oecologia, 151, 521-529.

TAKIMOTO G., 2003. Adaptive plasticity in ontogenetic niche shifts stabilizes consumerresource dynamics. American Naturalist, 162, 93-109.

THIOULOUSE J., CHESSEL D., DOLÉDEC S., OLIVIER J.M., 1997. ADE-4: a multivariate analysis and graphical display software. Statistics and Computing, 7, 75-83.

THOMAS G., ECKMANN R., 2007. The influence of eutrophication and population biomass on common whitefish (Coregonus lavaretus) growth - the Lake Constance example revisited. Canadian Journal of Fisheries and Aquatic Sciences, 64, 402-410.

ZARET T.M., 1980. Predation and freswater communities. Yale University Press, New Haven, Conecticut. 
